\title{
Board Characteristics and Financial Reporting Quality among Jordanian Listed Companies: Proposing Conceptual Framework
}

\author{
Ebraheem Saleem Salem Alzoubi \\ School of Accountancy, College of Business, Universiti Utara Malaysia \\ 06010 UUM Sintok, Kedah, Malaysia \\ E-mail: he03ma@gmail.com
}

Received: February 24, 2012 Accepted: March 30, 2012 Published: June 1, 2012

doi:10.5296/ajfa.v4i1.1442ＵRL: http://dx.doi.org/10.5296/ajfa.v4i1.1442

\begin{abstract}
The East Asian financial crises in 1997/1998 as well as the worldwide collapses exposed the considerable need of firms in different countries to progress the corporate governance perform in order to recuperate the investors' confidence of financial reporting quality (FRQ). To achieve this, the present research examines the relationship between board characteristics and earning management (EM). It is argued that effective board can reduce EM and in turn increase FRQ.
\end{abstract}

Keywords: Board of directors, corporate governance, earning management, financial reporting quality. 


\section{Introduction}

Several corporate collapses such as BCCI and Maxwell as well as fluctuating economic climate propelled the development of good corporate governance for disciplining listed companies (Barrier, 2002; Cadbury Report, 1992). The Cadbury Report (1992) concerned with corporate governance mechanisms being compromised by reduced FRQ. The East Asia financial crisis in 1997/1998 also highlighted weak and poor of both governance along with governance standards that were ultimately blamed for the crisis (Hashim, 2009; Nam \& Nam, 2004). This in turn effected in assurance of investors in East Asia capital market (Abdul Rahman \& Haniffa, 2005; Hashim, 2009; Leng \& Chang, 2011). These scenarios have strained the concentration to improve worldwide corporate governance as well as to improve FRQ for maintaining the assurance of the investors (Pergola, 2005).

Jordan also experienced several financial collapses such as Shamayleh Gate (JFED, 2003). This has forced Jordan to consolidate corporate governance foundations and principles to promote transparency, accountability and the rule of law (JFED, 2003). To assist Jordan in this, this paper aims to propose several board characteristics that need to be considered in depth.

The remaining of this paper is organized as follows: Section 2 introduces the background of the study. Section 3 discusses the literature review. Section 4 presents the conceptual framework and hypotheses development. Lastly Section 5 presents the summary and conclusions.

\section{Background}

Jordan is a small country with partial natural resources, the legal and organizational structures have been amended, and also significant measures took to reorganize, liberalize and raise the national economy openness. Its financial market is aiming to the principles of equality, transparency, and effectiveness. It seeks for afford a safe environment for its listed securities at the same time as protecting the rights of the investors. In view of the fact that, Jordan is one of the countries where users depend on accounting numbers intended for making decisions, it is of enormous significance to consider the area under discussion of EM to protect those users from being mislead. Also, by reason of the lack of studies about EM in Jordan, this study aims at providing evidence concerning EM practices (Ahmed \& Ali, 2009).

\section{Literature Review}

\subsection{Financial Reporting Quality}

Financial reports playing the main medium as the information discrete to the outside user (Wild, 1996), in addition, Financial Accounting Standard Board (FASB) (2008, p.13) stated that: "The objective of financial reporting is to provide financial information about the reporting entity that is useful to present and potential equity investors, lenders, and other creditors in making decisions in their capacity as capital providers. Information that is decision useful to capital providers may also be useful to other users of financial reporting who are not capital providers”. As a result, the information that considered as high quality 
can decrease the agency cost problem by means of closing the information asymmetry gap that occurs between shareholders and management (Karamanou \& Vafeas, 2005) ${ }^{1}$.

On the other hand, there is no consent like to what are comprised of FRQ. For instance, Both Blue Ribbon Commission (BRC) (1999) and Sarbanes-Oxley act (SOX) (2002) necessitate auditors to converse the methods and acceptability of FRQ. Furthermore, Jonas and Blanchet (2000, p. 353) stated that: "in light of these new requirements, auditors, audit committee members, and management are now struggling to define FRQ”. More willingly than FRQ identified, prior research literature (Barth et al., 2008; Nichols \& Wahlen, 2004) has been paying attention on issues such as EM, financial restatements, and fraud that perceptibly restrain high FRQ attainment and make use of them as an evidence of a breakdown the financial reporting process.

FRQ also is not observed directly (He et al., 2009). Arthur Levitt (1998) the United States of America (USA) Securities and Exchange Commission (SEC) former chairman said that: "high quality accounting standards ...improve liquidity and reduce capital costs" and claimed that: "quality information is the lifeblood of strong, vibrant markets. Without it, liquidity dries up. Fair and efficient markets cease to exist”. As a consequence, in order to find effective FRQ; there will be decisive need to establish suitable mechanisms of corporate governance. The paper concentrates on board of directors characteristics.

\subsection{Earning Management}

FRQ can be investigated from the perspective of EM, financial restatements, and fraud (Barth et al., 2008; Nichols \& Wahlen, 2004). The focus of this paper is EM. This is because it is the most committed fraud in the capital market (Ahmed \& Ali, 2009).

EM issue has been discussed by many pervious researchers (Healy \& Wahlen, 1999; Dechow \& Skinner, 2000; Lo, 2008; Schipper, 1989). For example, Schipper (1989, p.92) defined EM as: “...purposeful intervention in the external financial reporting process, with the intent of obtaining some private gains”. Furthermore, Healy and Wahlen (1999, p.368) stated that EM may occur: “... when managers use judgment in financial reporting and in structuring transactions to alter financial reports to either mislead some stakeholders about the underlying economic performance of the company or to influence contractual outcomes that depend on reported accounting numbers”. Arthur Levitt former SEC Chairman (1998) said: "Numbers Game", articulated the negative FRQ as a result of EM practice. Teets (2002) also stated that FRQ can be influenced by three decisions: (1) standard setters' decision; (2) accounting method used as chosen by management; and (3) management judgment and estimates in applying the selected substitutes. Additionally, Brown (1999, p.61) indicated that: "choices, judgments and estimates are an inevitable consequence of not being able to observe, measure and communicate economic value-added accurately and reliably”. Healy and Wahlen (1999) mentioned that managers are able to use their judgment in financial reporting

\footnotetext{
${ }^{1}$ Pergola (2005, p. 178) defined information asymmetry as: "the fact that the management has inside information about the true economic status of the firm that they may or may not share with stakeholders”.
} 
and in turn more management opportunities to earning manipulation for their profits and that did not replicate the fundamental firms' economics.

In short, EM definition is centered on the intent of managers, which is significantly hard to observe (Dechow \& Skinner, 2000; Lo, 2008; Wiedman, 2002). For that reason, deliberations over the measurement of EM issues are continuing through cause of the complexity in the distinguishing between the true belief of the management and the intention of management to earnings manipulation. So, figure 1 presents the distinction between fraud and EM as viewed through Dechow and Skinner (2000, p.239).

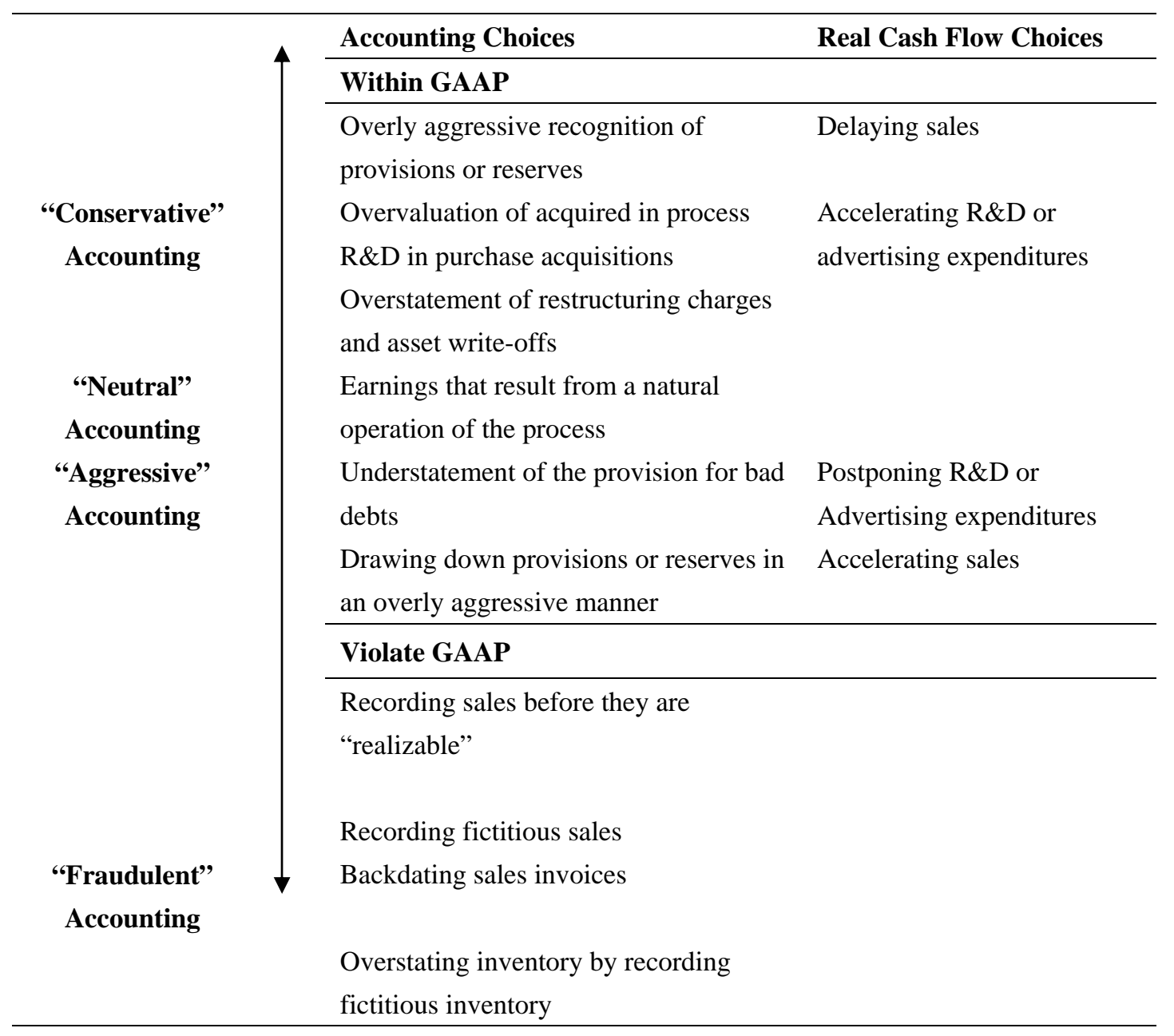

Figure 1. The Distinction between Earning Management and Fraud Source: Adapted from Dechow \& Skinner (2000)

Implicit in figure 1 is that managers are engage in EM practices as long as they have inducements to manage earnings. The previous literature (Dechow \& Skinner, 2000; Healy \& Wahlen, 1999; Jackson \& Pitman, 2001) showed three inducements for managers to manipulate earnings which are contractual incentives, market incentives and regulatory incentives. 
Managers engage in EM activities in order to get many incentives such as debt covenants, management compensation agreement, job security and union negotiations. These four incentives are examples of contractual situations. Peasnell et al. (2000a) indicated that shareholders exercise earnings for bonus and stock options for manager, this resulted in earnings manipulate for more benefits. Also, managers engage in EM as they recognize an association among reported earnings and the market value of the company. Burgstahler and Dichev (1997) confirmed that managers' manage earnings in order to reduce the forced transactions costs with stockholders. In addition, managers manage earnings to influence the regulators or government officials' action. Jackson and Pitman (2001) stated that managers might influence the actions of regulators or government officials through managing the operations results, in that way minimizing political scrutiny and the regulation effects firms.

To recapitulate, it could be said that EM occur when there are incentives as well as opportunities for it. The question is that: how companies are able to get away with it? This question leads to the significant role played by corporate governance in safeguarding and improve FRQ.

\subsection{Corporate Governance}

Corporate governance indicates the acting governing firms in order to protect the shareholders' interests. The ownership and control separation has initiated the assortment of suitable corporate governance mechanisms to make sure a competent interest arrangement for both principals and agents. Shleifer and Vishny (1997) observed corporate governance from a simple agency viewpoint that dealing with the investors to make sure that they will acquire their investment back from the management. The agency theory apprehensions the problem of principal-agent in ownership and control separation of the firm and attends to the probable for agency problems (Fama \& Jensen, 1983; Jensen \& Meckling, 1976). The signed contracts among shareholders and managers in fact offer managers essential remaining rights control that generates chances to confiscate the funds of shareholders (Shleifer \& Vishny, 1997).

Corporate governance can be defined as: “... the system by which companies are directed and controlled. Boards of directors are responsible for the governance of their companies. The shareholders' role in governance is to appoint the directors and the auditors and to satisfy themselves that an appropriate governance structures is in place. The responsibilities of the board include setting the strategic aims, providing the leadership to put them into effect, supervising the management of the business and reporting to shareholders on their stewardship. The board's actions are subject to laws, regulations and the shareholders in general meeting” (Cadbury Report, 1992, p.15).

The above definition highlights the significant role of the boards as an agent to firms' direct and control in addition to communicate the accurate the fundamental financial information to shareholders (Ow-Yong \& Guan, 2000). The board of directors is supposed to do the role of monitoring in aid of shareholders (John \& Senbet, 1998) and has the major responsibility of firm' leading and directing in order to attain corporate objectives through intimately monitoring the actions of management and protecting the shareholders' interest (Abdullah, 2004). Additionally, the board is considered as the most influential and cost effectual 
mechanism of corporate governance for managers monitoring when pursuing actions that raise the value of firm (Abdullah \& Mohd-Nasir, 2004). The effective board presence is to make sure that the effective alignment of managers' and owners' interests and to stimulate the wealth and earnings of shareholders (Vethanayagam et al., 2006).

Due to the importance of board of directors as one of the corporate governance mechanisms, this paper intends to propose several characteristics of board of directors. Being equipped with this understanding enables Jordanian regulatory agencies to reduce EM and in turn increase FRQ.

\section{The Conceptual Framework and Hypothesis Development}

The characteristics of board of directors and their linkage with EM are integrated in one conceptual framework. Figure 2 illustrates the propose framework. In this conceptual framework, board characteristics and EM are independent and dependent variables respectively. The present study thus attempts to bridge the gap by providing a basis for discerning the impact of board characteristics on EM. Although the causal relationships among the constructs illustrated in Figure (2) seem to be straightforward, to our knowledge, the present study is the only one that holistically investigates the relationship between board characteristics and EM. Sections 4.1 till 4.5 will discuss the hypotheses that are developed from the conceptual framework.

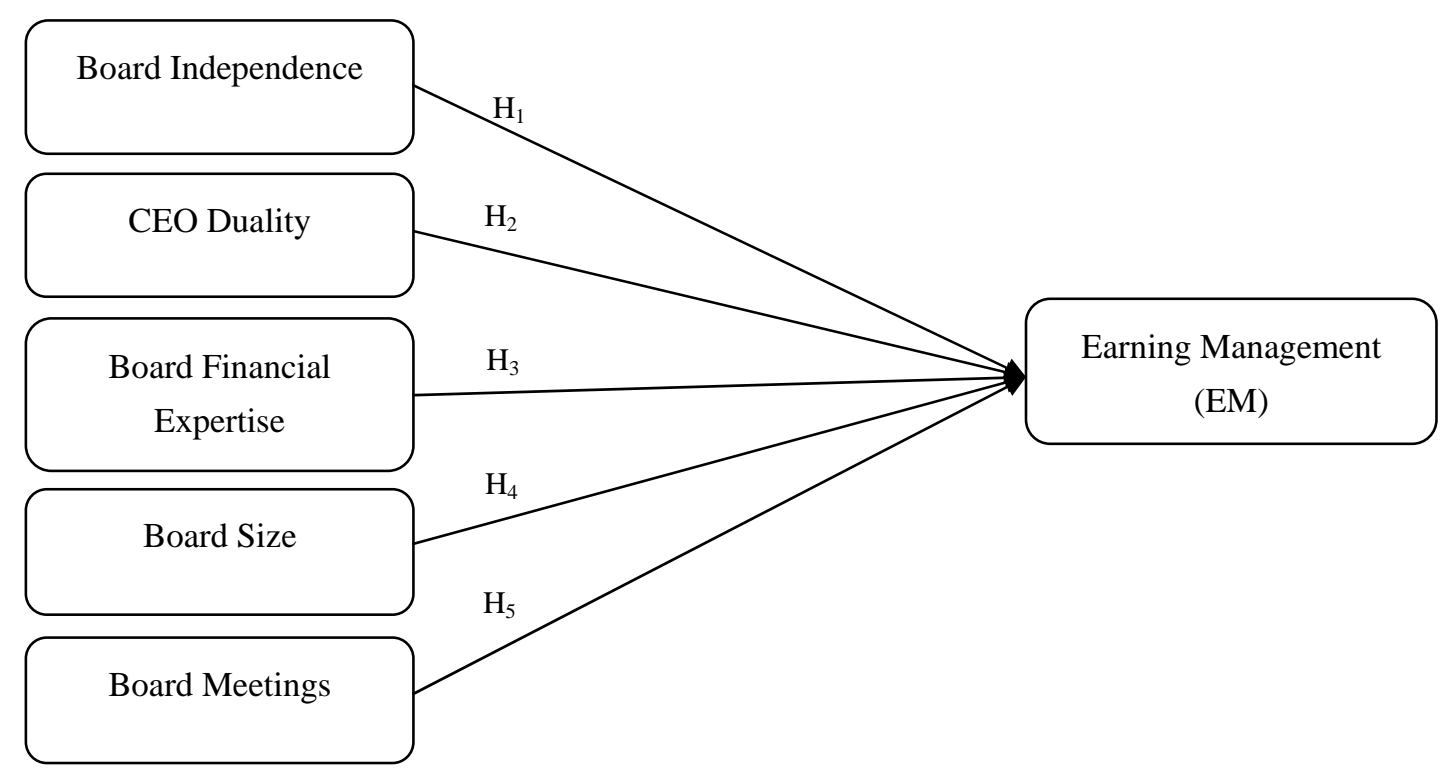

Figure 2. Board Characteristics and Earning Management

\subsection{Board Independence}

Majority of the prior studies on the association between corporate governance and EM documented a negative association between the presence of outside directors and EM (Bedard et al., 2004; Benkel, et al., 2006; Klein, 2002a; Niu, 2006; Osma, 2008; Peasnell et al., 2000a; 2000b; 2005; Xie et al., 2003).

Xie et al. (2003) and Klein (2002a) investigated the impact of different characteristics of boards on EM and found that companies with larger proportion of independent directors will 
be less likely engaging in EM than the one that have executive directors. This is supported by Peasnell et al. (2000a; 2000b; 2005) whereby they found that firms with a higher proportion of outside directors have less income-increasing accruals when earnings fall below the threshold. In other words, outside directors are more concerned with constraining income-increasing accruals.

More recently, Osma (2008) investigated the independent boards' effect on constraining research and development (R\&D) spending manipulation and uncovered that independent directors are capable of identifying and constraining EM represented by R\&D cuts. On the other hand, Park and Shin (2004) they found that independent outside directors per se did not decrease EM, while outside directors from financial intermediaries and active institutional shareholders did decrease EM. This highlights the importance of appointing outside directors with financial expertise. Niu (2006) further supported all these findings by saying that the level of independence of board composition is negatively related to the level of abnormal accruals. Benkel, et al. (2006) and Osam amd Noguer (2007) also observed these phenomena whereby they found that boards and audit committees with higher independence are associated with reduced EM levels.

Jaggi et al. (2009) examined whether independent boards provide effective EM monitoring in firms operating in the family ownership environment in Hong Kong. The results indicated that independent boards provide effective monitoring of EM. Nevertheless, they found that the monitoring effectiveness of independent boards was moderated in family-controlled firms, which suggests that increasing the proportion of independent directors to strengthen board monitoring is unlikely to be effective in family-controlled firms. Lo et al. (2010) investigated whether good governance structures help constrain management's opportunistic behaviors measured through transfer pricing manipulations. They documented that firms with independent boards' are less likely to engage in transfer pricing manipulations. However, Abdul Rahman and Ali (2006) found that the relationship between board independence and EM was insignificant. Siregar and Utama (2008) also did not found evidence that firms with independent boards engage in informative EM. These findings are contrary to other studies.

From the aforementioned discussion, it is argued that there is a potential relationship between board independence and EM. Thus, the following hypothesis is developed:

$H_{1}$ : The independence of the board of directors is negatively related to earning management among Jordanian listed companies.

\subsection{CEO Duality}

The separation roles among chairman and CEO are well recommended to avoid substantial power concentration whereby similar individual executes both roles (Cadbury Report, 1992; JCGC, 2009). International Australian guidelines Standards (2003) stipulate that board monitoring role will be jeopardized if board chairperson is also the CEO of the firm (Davidson et al., 2005).

Bowen et al. (1986) stated that the separation of roles between chairman and CEO was significant in preventing EM activities. They discovered that earnings smoothing activities 
were higher amongst CEO duality firms. This was consistent with a study conducted in year 2001 in Malaysian whereby firms with CEO duality were positively related with EM. Abdul Rahman and Haniffa (2005) supported that by saying companies with CEO duality did not perform well and incline to do EM.

Based on the above discussion, it is argued that there is a potential relationship between CEO duality and EM. Thus the following hypothesis is proposed:

$\mathrm{H}_{2}$ : $\mathrm{CEO}$ duality is positively related to earning management among Jordanian listed companies.

\subsection{Board Financial Expertise}

In line with dependency theory, the role of directors as an advice source as well as counsel for the CEO is essential in increasing firms' valued (Daily et al., 2003). It is significant for both inside and outside directors to play an efficient role in improving FRQ to provide access to the firms' needed resources such as financial, governance and firm-specific expertise (Bedard et al., 2004; JCGC, 2009). Barton et al. (2004, p.61) suggested that to do their tasks effectively the boards must have the ability for "asking management tough questions, actively helping to set corporate strategy, monitoring risk management, contributing to CEO successions plan and ensuring that companies set and meet their financial and operating targets". So far, this can only be achieved if the board has the vital expertise to fully embrace such duties. According to Reilly (2003), governance strategic business direction and finance are three areas that every director should master in.

Xie et al. (2003) uncovered that boards of directors with corporate or investment banking backgrounds are negatively related to the level of EM. This suggests that independent directors with corporate and financial backgrounds are critical to deter managed earnings. Bedard et al. (2004) observed that the presence of financial expert in the audit committee was negatively related with the probability of aggressive EM. Karamanou and Vafeas (2005) reported that the expertise of audit committee was positively related to the market reaction of earnings forecast. Additionally, Park and Shin (2004) found that the presence of officers from financial intermediaries in the board can limit abnormal accruals as the unmanaged earnings are below the target. They said that experienced outside board members able to understand the firm and its people better and consequently improve their governance competencies.

Based on the above discussion, it can be said that there is a potential relationship between board financial expertise and EM. Thus the following hypothesis is proposed:

$H_{3}$ : The financial expertise of the board of directors is negatively related to earning management among Jordanian listed companies.

\subsection{Board Size}

Monks and Minow (2011) and Lipton and Lorsch (1992) stated that larger boards are able to commit more time and effort, whereas smaller boards are able to commit less time and effort, to overseeing management. Klein (2002b) extended this argument by saying that board 
monitoring is positively associated with larger boards because of their ability to distribute the workload to many people.

Xie et al. (2003) uncovered EM is less likely to take place in firms with larger boards. Yu (2008) found that small boards seem more prone to failure to detect EM. Implicit in these findings is that smaller boards incline to be influenced by the management or dominated by block-holders, as larger boards are more capable of monitoring the top management actions.

Abdul Rahman and Ali (2006) and Kao and Chen (2004) found a significant positive association between board size and the empirical indicator of EM. However, as Xie et al. (2003) found a negative association between EM and board size. Their different results might be because of different types of EM adopted or different markets and corporate governance practice.

Based on the above discussion, it can be said that there is a potential relationship between board size and EM. Thus the following hypothesis is proposed:

$\mathrm{H}_{4}$ : The size of board of directors is negatively related to earning management among Jordanian listed companies.

\subsection{Board Meetings}

Directors on boards that meet regularly are more likely to discharge their duties in accordance with interests of shareholders since more time can be devoted to monitoring issues such as EM, conflicts of interest and monitoring management. On the other hand, boards that hardly ever meet may have no time to find out about such complex issues and may perhaps have time only to rubber stamp management plans.

There are few studies of the impact on board meeting frequency on EM. Xie et al. (2003) argued that a board that meets rarely may only have time for signing off management plans and listening to presentations; hence, they may not have time to focus on issues such as EM. In other words they found that EM was significantly negatively related to the number of board meetings. On the other hand, Adams et al. (2008) found that directors who primarily monitor management perceives that they participate less in boardroom discussion than other directors and that the CEO often asks them for advice.

Bearing in mind the above conflicting views, this paper still believes that there is a potential relationship between board meeting and EM. Thus the following hypothesis is proposed:

$H_{5}$ : The number of board of directors meeting negatively related to earning management among Jordanian listed companies.

\section{Summary and Conclusions}

Issues relating to EM and its effects on the FRQ are discussed. Previous studies provide evidence on the existence of EM when managers have both the incentive and opportunity to manage earnings. Three main factors (i.e. contractual incentives, market incentives and regulatory incentives) are identified to create motives for EM that lead to lower FRQ. While previous research suggests that EM does occur, recent research demonstrates the critical role 
of corporate governance in monitoring EM activities and improving FRQ. This paper, however, discusses one of the elements of corporate governance which is board characteristics.

To be more specific this paper intends to investigate the roles of the board of directors on EM among Jordanian listed companies. The study serves as a wake-up call for reforming the management and boards in Jordan. To achieve this five board characteristics are proposed, namely, board independent, CEO duality, board financial expertise, board size and board meeting. In turn five hypotheses are developed to validate the hypothesis survey research will be undertaken.

\section{References}

Abdul Rahman, R., \& Ali, F. H. M. (2006). Board, audit committee, culture and earnings management: Malaysian evidence. Managerial Auditing Journal, 21(7), 783-804. http://dx.doi.org/10.1108/02686900610680549

Abdul Rahman, R., \& Haniffa, R. M. (2005). The effect of role duality on corporate performance in Malaysia. Corporate ownership and control, 2(2), 40-47.

Abdullah, S. N. (2004). Board composition, CEO duality and performance among Malaysian listed companies. Corporate Governance, 4(4), 47-61. http://dx.doi.org/10.1108/14720700410558871

Abdullah, S. N., \& Mohd Nasir, N. (2004). Accrual management and the independence of the board of directors and audit committees. IIUM Journal of Economics and Management, 12(1), 49-80.

Adams, R., Hermalin, B., \& Weisbach, M. (2008). The role of boards of directors in corporate governance: A conceptual framework and survey: National Bureau of Economic Research Cambridge, Mass., USA. http://dx.doi.org/10.3386/w14486

Ahmed, A., \& Ali, A. (2009). Earnings management practices from the perspective of external and internal auditors: Evidence from Jordan. Managerial Auditing Journal, 24(1), 58-80. http://dx.doi.org/10.1108/02686900910919901

Barrier, M. (2002).The crisis in governance. Internal Auditor. August. 50-53.

Barth, M. E., Landsman, W. R., \& Lang, M. H. (2008). International accounting standards and accounting quality. Journal of Accounting Research, 46(3), 467-498. http://dx.doi.org/10.1111/j.1475-679X.2008.00287.x

Barton, D., Coombes, P., \& Wong, S. C. Y. (2004). Asia's governance challenge. McKinsey Quarterly(2), 54-61.

Bedard, J., Chtourou, S. M., \& Courteau, L. (2004). The effect of audit committee expertise, independence, and activity on aggressive earnings management. Auditing: Journal of Practice \& Theory, 23(2), 13-36. 
Benkel, M., Mather, P., and Ramsay, A. (2006). The Assassination Between Corporate Governance and Earnings Management: The Role of Independent. Corporate Ownership and Control, 3.

Blue Ribbon Committee on Improving the Effectiveness of Corporate Audit Committees (BRC) (1999), Report and Recommendations of Blue Ribbon Committee on Improving the Effectiveness of Corporate Audit Committees, New York and Washington, DC, NYSE and NASD.

Bowen, R. M., Burgstahler, D., \& Daley, L. A. (1986). Evidence on the relationships between earnings and various measures of cash flow. Accounting Review, 61, 713-725.

Brown, P. R. (1999). Earnings Management a Subtle (and Troublesome) Twist to Earnings Quality. Journal of Financial Statement Analysis, 4(2), 61-64.

Burgstahler, D., \& Dichev, I. (1997). Earnings management to avoid earnings decreases and losses. Journal of Accounting and Economics, 24(1), 99-126. http://dx.doi.org/10.1016/S0165-4101(97)00017-7

Cadbury Committee Report (1992). The Financial Aspects of Corporate Governance. Gee and Co. Ltd. London.

Daily, C. M., Dalton, D. R., \& Cannella, A. A. (2003). Corporate governance: Decades of dialogue and data. Academy of Management Review, 28(3), 371-382.

Davidson, R., Goodwin-Stewart, J., \& Kent, P. (2005). Internal governance structures and earnings management. Accounting and Finance, 45(2), 241-267. http://dx.doi.org/10.1111/j.1467-629x.2004.00132.x

Dechow, P., \& Skinner, D. (2000). Earnings management: Reconciling the views of accounting academics, practitioners, and regulators. Accounting Horizons, 14(2), 235-250. http://dx.doi.org/10.2308/acch.2000.14.2.235

Fama, E. F., \& Jensen, M. C. (1983). Separation of ownership and control. Journal of Law and Economics, 26(2), 301-325. http://dx.doi.org/10.1086/467037

FASB. Completing the February 2006 Memorandum of Understanding: A progress report and timetable for completion September 2008. Available at: http://72.3.243.42/intl/MOU_09-11-08.pdf (accessed February 17 2008).

Hashim, H. A. (2009). Board of directors, ownership structure, ethnicity and earnings quality: Malaysian Evidence. Universiti Malaya, Kuala Lumpor.

He, L., Labelle, R., Piot, C., \& Thornton, D. B. (2009). Board monitoring, audit committee effectiveness, and financial reporting quality: Review and synthesis of empirical evidence. Journal of Forensic \& Investigative Accounting, 1(2), 1-41.

Healy, P., \& Wahlen, J. (1999). A review of the earnings management literature and its implications for standard setting. Accounting Horizons, 13(14), 365-383. http://dx.doi.org/10.2308/acch.1999.13.4.365 
Jackson, S., \& Pitman, M. (2001). Auditors and earnings management. CPA Journal, 71(7), 38-45.

Jaggi, B., Leung, S., \& Gul, F. (2009). Family control, board independence and earnings management: Evidence based on Hong Kong firms. Journal of Accounting and Public Policy, 28(4), 281-300. http://dx.doi.org/10.1016/j.jaccpubpol.2009.06.002

JCGC. (2009). Corporate Governance Code for Shareholding Companies Listed on the Amman Stock Exchange http://www.jsc.gov.jo/Public/english.aspx?Lang=1\&Page_Id=225\&Menu_ID2=257

Jensen, M. C., \& Meckling, W. H. (1976). Theory of the firm: Managerial behavior, agency costs and ownership structure. Journal of Financial Economics, 3(4), 305-360. http://dx.doi.org/10.1016/0304-405X(76)90026-X

JFED (Jordanian Forum for Economic Development). (2003). The state of corporate governance in Jordan. The Economic Policy Dialogue, (1), 1-6.

John, K., \& Senbet, L. W. (1998). Corporate governance and board effectiveness. Journal of Banking \& Finance, 22(4), 371-403. http://dx.doi.org/10.1016/S0378-4266(98)00005-3

Jonas, G. J., \& Blanchet, J. (2000). Assessing quality of financial reporting. Accounting Horizons, 14(9), 353-363. http://dx.doi.org/10.2308/acch.2000.14.3.353

Kao, L., \& Chen, A. (2004). The effects of board characteristics on earnings management. Corporate Ownership \& Control, 1(3), 96-107.

Karamanou, I., \& Vafeas, N. (2005). The association between corporate boards, audit committees, and management earnings forecasts: An empirical analysis. Journal of Accounting Research, 43(3), 453-486. http://dx.doi.org/10.1111/j.1475-679X.2005.00177.x

Klein, A. (2002a). Economic determinants of audit committee independence. Accounting Review, 77(7), 435-452. http://dx.doi.org/10.2308/accr.2002.77.2.435

Klein, A. (2002b). Audit committee, board of director characteristics, and earnings management. Journal of Accounting and Economics, 33(3), 375-400. http://dx.doi.org/10.1016/S0165-4101(02)00059-9

Leng, A., \& Chang, A. (2011). The impact of corporate governance practices on firms' financial performance: Evidence from Malaysian companies. ASEAN economic bulletin, 21(3), 308-318. http://dx.doi.org/10.1355/AE21-3D

Levitt, A.L. (1998). The Numbers Game: Remarks by Chairman Arthur Levitt to the NYU Centre for Law and Business, New York.

Lipton, M., \& Lorsch, J. W. (1992). Modest Proposal for Improved Corporate Governance, A. Bus. Law., 1(1), 59-77.

Lo, A. W. Y., Wong, R. M. K., \& Firth, M. (2010). Can corporate governance deter management from manipulating earnings? Evidence from related-party sales transactions in 
China. Journal of Corporate Finance, 16(2), 225-235. http://dx.doi.org/10.1016/j.jcorpfin.2009.11.002

Lo, K. (2008). Earnings management and earnings quality. Journal of Accounting and Economics, 45(2-3), 350-357. http://dx.doi.org/10.1016/j.jacceco.2007.08.002

Monks, R. A. G., \& Minow, N. (2011). Corporate governance: Wiley.

Nam, S. W., \& Nam, I. C. (2004). Corporate governance in Asia: recent evidence from Indonesia, Republic of Korea, Malaysia, and Thailand: Asian Development Bank Institute.

Nichols, D. C., \& Wahlen, J. M. (2004). How do earnings numbers relate to stock returns? A review of classic accounting research with updated evidence. Accounting Horizons, 18(4), 263-286. http://dx.doi.org/10.2308/acch.2004.18.4.263

Niu, F. F. (2006). Corporate governance and the quality of accounting earnings: a Canadian perspective. International Journal of Managerial Finance, 2(4), 302-327. http://dx.doi.org/10.1108/17439130610705508

Osma, B. G. (2008). Board independence and real earnings management: the case of R\&D expenditure. Corporate Governance: An International Review, 16(2), 116-131. http://dx.doi.org/10.1111/j.1467-8683.2008.00672.x

Osma, B. G., \& Noguer, B. G. A. (2007). The effect of the board composition and its monitoring committees on earnings management: Evidence from Spain. Corporate Governance: An International Review, 15(6), 1413-1428. http://dx.doi.org/10.1111/j.1467-8683.2007.00654.x

Ow-Yong, K., \& Guan, C. (2000). Corporate Governance Codes: a comparison between Malaysia and the UK. Corporate Governance: An International Review, 8(2), 125-132. http://dx.doi.org/10.1111/1467-8683.00190

Park, Y. W., \& Shin, H. H. (2004). Board composition and earnings management in Canada. $\begin{array}{llll}\text { Journal of } \quad \text { Corporate } & \text { Finance, } & \text { 431-457. }\end{array}$ http://dx.doi.org/10.1016/S0929-1199(03)00025-7

Peasnell, K. V., Pope, P., \& Young, S. (2000a). Accrual management to meet eranings targets: UK evidence pre and post Cadbury. The British Accounting Review, 32(4), 415-445. http://dx.doi.org/10.1006/bare.2000.0134

Peasnell, K.V., Pope, P.F., \& Young, S. (2000b). Detecting Earnings Management Using Cross-Section a Abnormal Accruals Models. Accounting and Business Research, Vol. 30: pp. 313-326. http://dx.doi.org/10.1080/00014788.2000.9728949

Peasnell, K. V., Pope, P. F., \& Young, S. (2005). Board monitoring and earnings management: do outside directors influence abnormal accruals? Journal of Business Finance \& Accounting, 32(7\&8), 1311-1346. http://dx.doi.org/10.1111/j.0306-686X.2005.00630.x

Pergola, T. M. (2005). Management entrenchment: Can it negate the effectiveness of recently legislated governance reform. Journal of American Academy of Business, 6(2), 177-183. 
Reilly, S. (2003). Competency and training. Selected Issues in Corporate Governance: Regional and Country Experiences, United Nations Conference on Trade and Development New York and Geneva., 36-38.

Sarbanes-Oxley Act (SOX). (2002). Public Law No. 107-204. GPO: Washington, DC.

Schipper, K. (1989). Commentary on earnings management. Accounting Horizons, 3(4-5), 91-102.

Shleifer, A., \& Vishny, R.W. (1997). A survey of corporate governance. Journal of Finance, 52(2), 737-783.

Siregar, S. V., \& Utama, S. (2008). Type of earnings management and the effect of ownership structure, firm size, and corporate-governance practices: Evidence from Indonesia. The International Journal of Accounting, 43(1), 1-27. http://dx.doi.org/10.1016/j.intacc.2008.01.001

Teets, W. R. (2002). Quality of earnings: An introduction to the issues in accounting education special issue. Issues in Accounting Education, 17(4), 335-360. http://dx.doi.org/10.2308/iace.2002.17.4.335

Turley, S., \& Zaman, M. (2004). The corporate governance effects of audit committees. Journal of Management and Governance, 8(3), 305-332. http://dx.doi.org/10.1007/s10997-004-1110-5

Vafeas, N. (2005). Audit committees, boards, and the quality of reported earnings. $\begin{array}{lll}\text { Contemporary accounting 1093-1122. } & \text { 22(4), research, }\end{array}$ http://dx.doi.org/10.1506/1QYN-2RFQ-FKYX-XP84

Vethanayagam, J., Yahya, S., \& Haron, H. (2006). Independent non-executive directors, managerial ownership and firm performance in Malaysian public listed companies. Paper presented at the Proceeding Symposium on Accountability, Governance and Performance, Griffith University.

Wiedman, C. (2002). The power of auditors. CA Magazine, 135(10), 39-42.

Wild, J. J. (1996). The audit committee and earnings quality. Journal of Accounting, Auditing \& Finance, 11(2), 247-276.

World Bank. (2005). Reports on the Observance of Standards and Code (ROSC) in Jordan. From www.worldbank.org/ifa/orsc_aa_jor.pdf

Xie, B., Davidson III, W. N., \& DaDalt, P. J. (2003). Earnings management and corporate governance: the role of the board and the audit committee. Journal of Corporate Finance, 9(3), 295-316. http://dx.doi.org/10.1016/S0929-1199(02)00006-8

$\mathrm{Yu}$, F. F. (2008). Analyst coverage and earnings management. Journal of Financial Economics, 88(2), 245-271. http://dx.doi.org/10.1016/j.jfineco.2007.05.008 